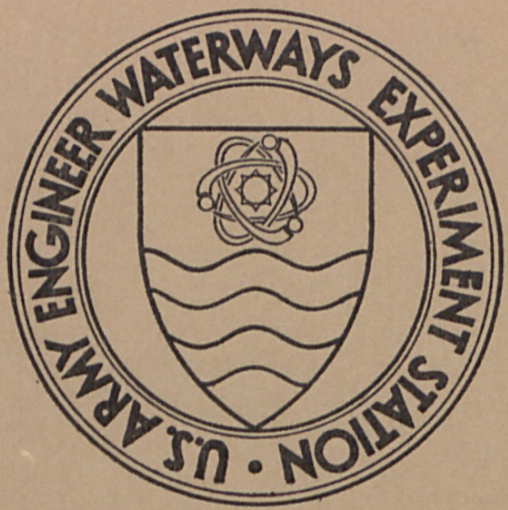

MISCELLANEOUS PAPER S-70-15

\title{
ORIGIN OF THE ST. FRANCIS SUNK LANDS ARKANSAS AND MISSOURI
}

\author{
by \\ R. T. Saucier
}

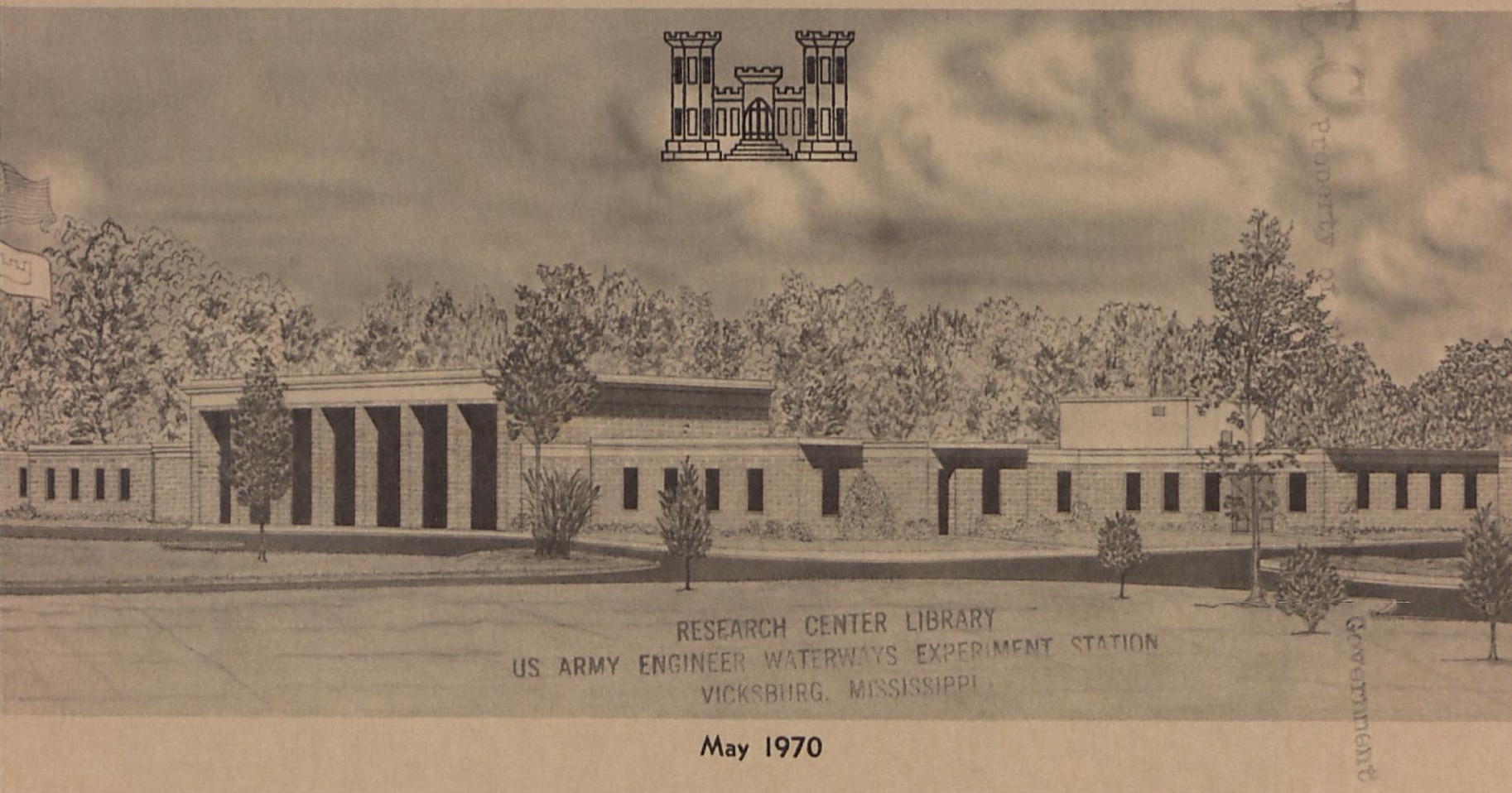

Prepared by U. S. Army Engineer Waterways Experiment Station, Vicksburg, Mississippi 


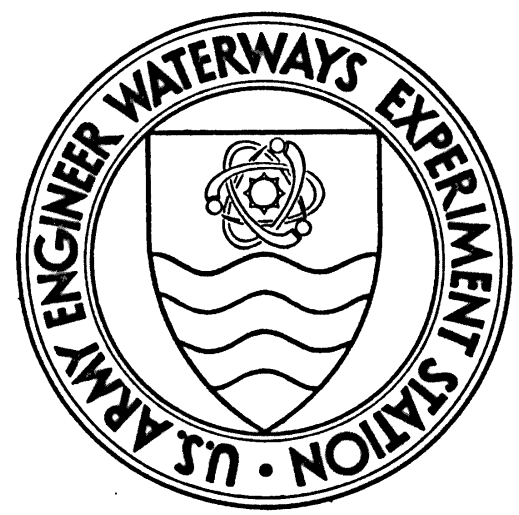

MISCELLANEOUS PAPER S-70-15

\section{ORIGIN OF THE ST. FRANCIS SUNK LANDS ARKANSAS AND MISSOURI \\ by}

R. T. Saucier

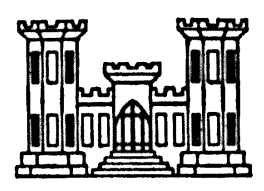

May 1970

Prepared by U. S. Army Engineer Waterways Experiment Station, Vicksburg, Mississippi 
FOREWORD

This paper was prepared by Dr. R. T. Saucier of the Geology Branch, Soils Division, U. S. Army Engineer Waterways Experiment Station (WES), for publication in the Bulletin of the Geological Society of America. Observations instrumental in the formulation of the concepts and conclusions presented in this paper were made during large-scale engineering-geologic mapping programs conducted by the WES Geology Branch for the U. S. Army Engineer District, Memphis, and the President, Mississippi River Commission. Preparation of the paper was authorized by the U. S. Army Engineer Division, Lower Mississippi Valley; the paper was reviewed and approved by the office, Chief of Engineers.

Director of WES during preparation of this paper was COL Levi A. Brown. Technical Director was Mr. F. R. Brown. 


\section{ABSTRACT}

The New Madrid earthquake, a succession of shocks in 1811 and 1812 in the northern portion of the Lower Mississippi Valley, caused earth waves, fissuring, sand blows, landslides, uplift, subsidence, and related phenomena over an area of thousands of square miles. However, considerable doubt is cast over the narrative accounts and evidence cited for assignment of the St. Francis Sunk Lands to the list of earthquake effects. Origin of these features as a result of alluvial drowning of several relict braided-stream channels by a Mississippi River crevasse channel appears to be a more tenable explanation. Excluding the sunk lands from consideration appreciably diminishes the southwestern extent of the area of discernible earthquake effects and helps subordinate the role of topographic and surface geologic features in calculating seismic risk zonation in the area. 
IINTRODUCTION

The northern portion of the Lower Mississippi Valley (Fig. 1) was devastated in late 1811 and early 1812 by a succession of earthquakes designated collectively the New Madrid earthquake (Fuller, 1912). This earthquake, primarily affecting northeastern Arkansas, southeastern Missouri, and western Kentucky and Tennessee, ranks as one of the greatest earthquakes of recorded history (Eppley, 1965) and probably was as intense and possibly had as great an effect on the natural environment as did the Alaskan earthquake of 1964 (Hansen and others, 1966).

Unfortunately for earth scientists, the earthquake occurred at a time when the affected area was sparsely populated and essentially unknown scientifically. Studies of topographic changes resulting from the earthquake consequently have had to be based on often exaggerated, inaccurate, and sometimes fanciful narratives prepared at the time and reports by trained observers (largely naturalists) who travelled in the region from 10 to 100 years after the earthquake. Apparently even the more sciential observers ventured only short distances from and/or recorded little about what happened beyond the more populated areas along the Mississippi River. Large portions of the affected region, including the St. Francis Sunk Land area, apparently were not visited for the first time by geologists until 35 years after the 1811-1812 event (Lyell, 1849).

Many of the conclusions drawn regarding the effects of the earthquake reflect the wholly inadequate knowledge of the topography of the area' before the earthquake and the complete absence of knowledge of 


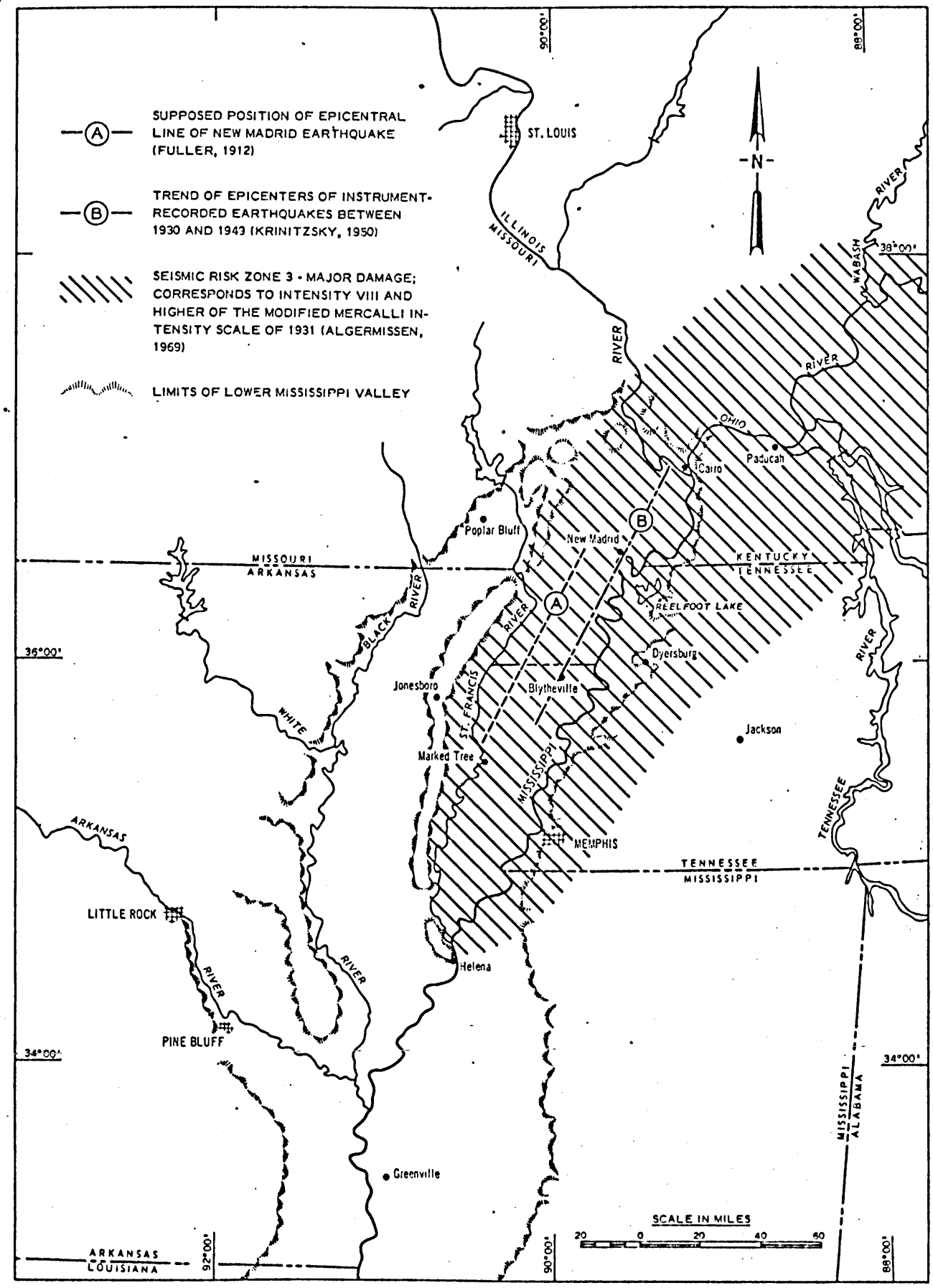

Figure 1. The New Madrid earthquake region; including locations of epicentral lines and seismic risk zonation. 
Mississippi alluvial valley history and can be questioned and sometimes rejected in light of present knowledge. Such is felt to be the case concerning the origin of the St. Francis Sunk Lands, features which comprise the most areally extensive and possibly the most topographically significant effect attributed to the earthquake. Evidence will be presented indicating that the formation of the sunk lands may well be completely unrelated to the New Madrid earthquake or preceeding ones and that the sunk lands may not have even been modified topographically by the earthquake. However, it is to be emphasized that the proposed deletion of the St. Francis Sunk Lands from the list of known earthquake effects js not intended to indicate or to imply that the New Madrid earthquake was less intense or of a lesser magnitude than is commonly accepted.

\section{ACKNOWLEDGMENTS}

Observations instrumental in the formulation of the concepts and conclusions presented in this: paper were made during large-scale engineering-geologic mapping programs conducted by the Geology Branch, U. S. Army Engineer Waterways Experiment Station, for the U. S. Army Engineer District, Memphis, and the President, Mississippi River Commission. Authorization by the U. S. Army Engineer Division, Lower Mississippi Valley, for preparation of the paper and approval by the Office, Chief of Engineers, for publication are acknowledged. Thanks are extended to Dr. C. R. Kolb and R. I. Kaufman for their review of this paper. 
THE NEW MADRID EARTHQUAKE

A compilation of records by observers in the central United States indicates the 1811-1812 succession of earthquakes consisted of 8 violent, 10 severe, and thousands of minor shocks during a period of about 3 months (Fuller, 1912). At least 3 of the shocks, starting with the initial one on December 16, 1811, had intensities of XII (Modified Mercalli Intensity Scale of 1931) and probable magnitudes of 8.5 (Richter scale) according to Eppley (1965) and Heigold (1968).

No instruments were available at that time to permit accurate calculations of the locations of epicenters. Fuller (1912) was able to derive an approximate epicentral line (Fig. 1) through an assessment of the geographic distribution of assumed earthquake effects. This line is in general accord with the trend of epicenters of instrumentally-recorded earthquakes of moderate intensity that occurred in the area between 1930 and 1949 (Krinitzsky, 1950). This trend (Fig. 1) is inferred as marking the location of a major fault zone responsible for the seismic activity in the area (McGinnis, 1963).

Narratives of the New Madrid earthquake leave no doubt that the more violent shocks caused earth waves, widespread fissuring, sand blows, and bank caving over a large area of the Mississippi alluvial valley (Eppley, I965). Even allowing for the incorrect inclusion of features such as sand dunes and prairie mounds (also referred to as mima mounds or pimple mounds) which often have been mistaken for sand blows, indications are that thousands of square miles of the alluvial valley. were affected. Landslides apparently occurred at frequent intervals along the bluffs just east of the Mississippi 
River in Kentucky and Tennessee, an area of about $15 \mathrm{sq}$ miles south of New Madrid, Missouri (Fig. 1), was uplifted at least several feet (the Tiptonville dome), and an area of several square miles subsided, contributing to the formation of Reelfoot Lake (Fig. 1). Evidence. is inconclusive; however, there are indications that faulting also occurred, particularly in the bed of the Mississippi River near New Madrid (Saucier, 1964).

THE ST. FRANCIS SUNK LANDS

Excluding minor sloughs, the term "sunk land" was applied by Fuller (1912) and others to Reelfoot lake and to several similar features west of the Mississippi River in Arkansas and Missouri. The three largest'sunk land areas west of the river, referred to as Lake St. Francis, Hatchie Coon Sunk Lands, and Big Lake, are shown in Figure 2 and are collectively designated the St. Francis Sunk Lands.

Before flood control and drainage-improvement projects were implemented, the sunk "land areas were characterized by broad, shallow, and essentially permanent bodies of water and both seasonally inundated and perennially inundated swamps. Early accounts appear to have greatly exaggerated the extent of actual open water bodies. Shallow to deep swamp conditions probably prevailed in well over 90 percent of the total. sunk land area, judging from the first relatively accurate surveying and mapping performed during the late 1840's.

The more authoritative references on the New Madrid earthquake such as those of Fuller (1912), Shepard (1905), and Broadhead (1902) make no mention of the condition of the sunk lands at the time of the earthquake nor do they contain information as to when the sunk lands 


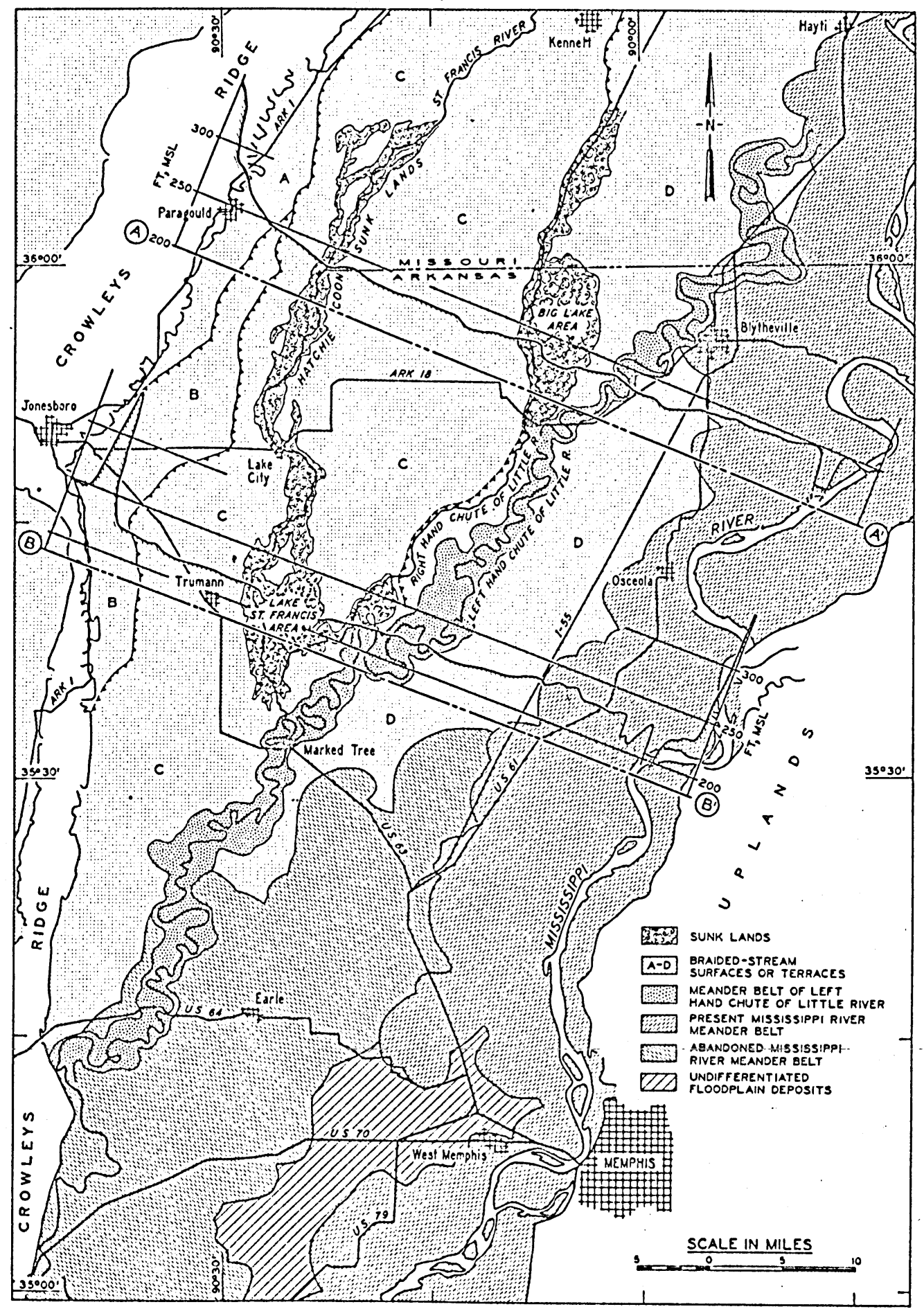

Figure 2. Location of the St. Francis Sunk Lands in relation to Mississippi alluvial valley terraces and meander belts. 
were first observed after this event. Early narratives and accounts mentioned in the literature contain repeated reference to Reelfoot Lake and to sunk lands near New Madrid; however, it is possible that the first association of the St. Francis Sunk Lands with the New Madrid earthquake did not occur before the 1840's (Broadhead, 1902). It is entirely possible that this first association was made on the basis of only two observations, that is, the presence of lakes and/or swamps in the midst of flat, sandy, and relatively well-drained forest and prairie land, and the presence of standing dead timber in the swamps and lakes. Cypress (Taxodium) and hardwood timber killed by submergence and left standing in shallow water was probably the most conspicuous feature of Reelfoot Lake for many years after its formation. Most writers, including Fuller (1912), tended to equate the maximum difference in elevation between the bottom of the sunk lands (including the depth of water) and the adjacent surfaces with the total amount of subsidence caused by the New Madrid earthquake. Estimates of this dimension range up to several tens of feet (Fuller, 1912), and include accounts of persons who claimed to be able to paddle canoes among the branches of submerged cypresses. Warping and lateral movement of the near-surface deposits resulting from subsidence of the basin floor (that is, the Tertiary "bedrock") were postulated as the mechanisms responsible for the creation of the sunk lands.

\section{A NEW COITCEPT OF ORIGIN}

The Quaternary alluvial deposits of the Lower Mississippi Valley east of Crowleys. Ridge (Fig. 2) consist of glacial outwash derived from waning Late Wisconsin glaciation and Holocene meander belt deposits of the Mississippi River and smaller streams. The depositional history 
of these deposits permits an alternate interpretation of the origin of the St. Francis Sunk Lands.

Four distinct surfaces or terraces, each characterized by relict braided-channel scars, are present on the outwash deposits as indicated in Figure 2. Archaeological evidence indicates the highest and oldest level, level A, is more than 10,000 years old while the lowest and youngest level, level $D$, might be less than 5,000 years old (Morse, 1969). Eastward migration of the river (through diversions to new courses) accompanied by progressive downcutting or degradation, probably because of a decreasing sediment load.and hence a greater stream competcnce, are believed to be the reasons for the formation of the terraces.

The change in regime of the Mississippi River from braided to meandering probably took place about 4,000 years ago (Saucier, 1968) and resulted in a cessation of the degradational trend and the beginning of a continuing aggradational trend. Because the Mississippi River has occupied only one meander belt along the eastern side of its valley north of the latitude of Marked Tree, Arkansas (Fig. 2), the resulting topographic situation in this area is a broad basin with the lowest elevations (see profiles $A-A^{\prime}$ and $B-B^{\prime}$, Fig. 2) lying about midway between the eastern uplands and Crowleys Ridge.

When a difference in elevation of 15 to $20 \mathrm{ft}$ or more occurred between the natural levee crests of the meandering Mississippi River and adjacent low floodplain areas, a situation developed conducive to a diversion of the river to a new course through the low areas of the floodplain to achieve a slightly steeper gradient. The Left Hand Chute of Little River (Fig. 2) apparently represents the latest (and best 
developed) of a series of abortive attempts of the river to do this by means of a major crevasse channel. Narrow meander belts of other crevasse channels similar to the Left Hand Chute of Little River occur between this stream and U. S. Hwy. 61 (Fig. 2) but are not delineated herein. The development of the Left Hand Chute of Little River is believed to have been between about 1000 and 1500 years ago on the basis of only meager stratigraphic and archaeologic evidence.

The development of natural levees along the Left Hand Chute of Little River is considered to be the primary mechanism in the formation of the St. Francis Sunk Lands, Before the crevasse channel developed and natural levees were present, local drainage and streams such as the St. Francis River flowed southward across the braidedstream surfaces as underfit streams within the confines of the broad, shallow relict braided channels. The St. Francis River apparently maintained a rather constant gradient of about $1.0 \mathrm{ft} / \mathrm{mile}$ past Marked Tree to where it joined the abandoned Mississippi River meander belt shown in Figure 2. However, with the development of the crevasse channel and the consequent relatively rapid natural levee growth, the St. Francis River and other minor drainage were intercepted and the downstream-most portions of the relict braided channels experienced pronounced alluvial drowning. These drowned areas are what comprise the St. Francis Sunk Lands.

Detailed geologic mapping in the area of Lake St. Francis (Saucier, 1964) has revealed the extent and configuration of the relict braided channels as indicated in Figure 3. This same illustration shows how the extent of Lake St. Francis as mapped in the 1840's (Government Land Office land plats) coincides almost exactly with the 


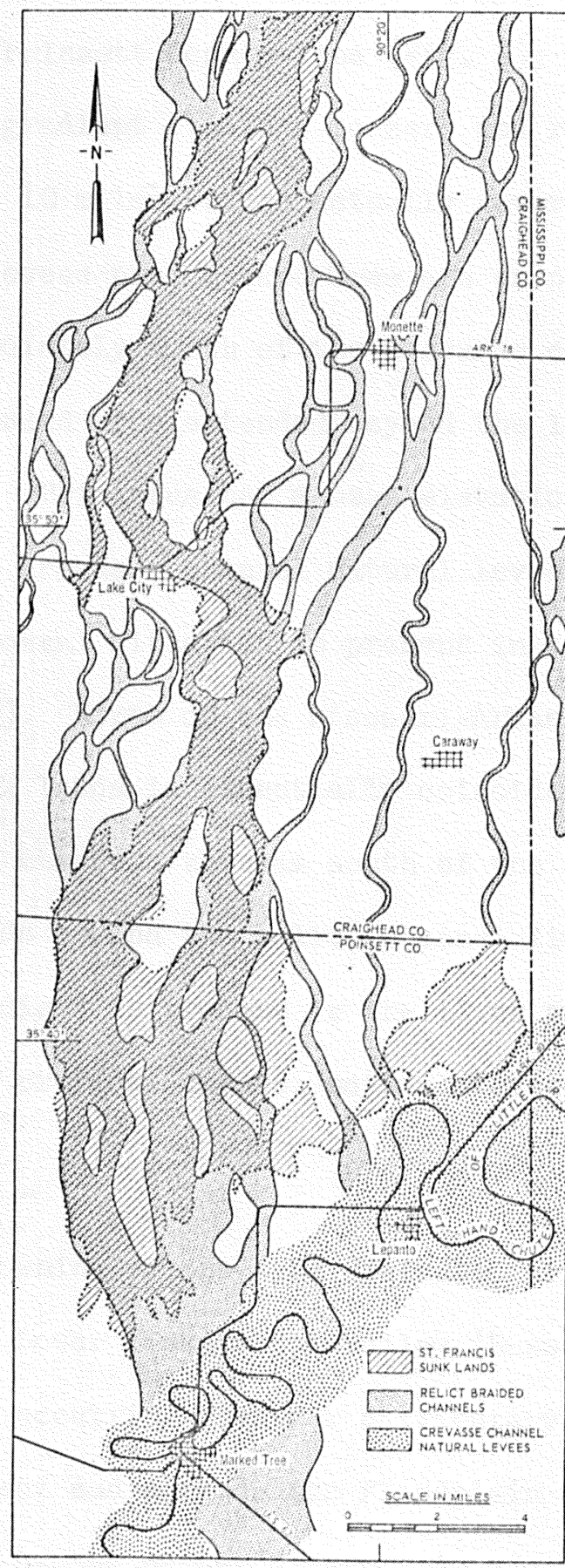

Figure 3. Relationship between the configuration of Lake St. Francis and the location and extent of relict braided channels. 
relict braided channels north of the meander belt of the Left Hand Chute of Little River. Longitudinal profiles along the relict braided channel show that a gradient of $1.0 \mathrm{ft} / \mathrm{mile}$ is present as far south as the Craighead-Poinsett County line (Fig. 3); however, below the. county line, the gradient flattens to zero and remains so over a distance of about 10 miles before actually reversing as the crevasse channel natural levees near Marked Tree are encountered. Only over a small area immediately north of the crevasse channel levees has the drowned or ponded area extended beyond the limits of the relict braided channels. This area has a mean elevation about 7 ft lower than the adjacent crevasse channel natural levees.

The same general situation is present in the Big Lake sunk land area (Fig. 2). North of the Missouri-Arkansas state line, the extent of the sunk lands is essentially coincident with the extent of relict braided channels whereas south of the state line, the ponded area extends beyond the relict channel limits. A similar shallowing of gradient is present in the lower part of the Big Lake area north of "the crevasse channel natural levees.

\section{DISCUSSION}

Alluvial drowning of the type discussed herein is a widespread phenomenon in the Lower Mississippi Valley (Russell, 1939; Saucier and Fleetwood, 1970), occurring wherever a tributary stream is forced to shallow its gradient and aggrade its floodplain in response to more rapid alluviation by the master stream. As a causal process in sunk land formation, alluvial drowning is compatible with all observable characteristics of these features. Standing dead timber is almost 
always one of the most outstanding attributes of alluvially drowned areas. The characteristic swamp or open-water conditions in features of this type persist until the depression finally aggrades to the level of the alluvial barrier and "normal" drainage returns, not uncommonly a matter of several hundred years.

Detailed geologic mapping in the area of the sunk lands (Saucier, 1964), in addition to providing evidence of alluvial drowing, has failed to indicate evidence supporting creation of the sunk lands as a result of earthquake activity. No faults, either in the sub-alluvial. Tertiary formations or on the braided-stream surfaces, have been identified in the vicinity of the sunk lands. Since the Left Hand Chute of Iittle River (the last significant source of sediments in the area) was essentially abandoned and inactive long before the earthquake, it is not likely that faults are present and hidden by an alluvial veneer. Moreover, there are no indications that the relict braided channels that contain the sunk lands were influenced in any way by major earthquakes preceeding the $1811-1812$ series.

The only other way that can be foreseen in which subsidence and sunk land formation could have resulted from an earthquake is through highly localized or differential densification of the coarse-grained glacial outwash deposits that everywhere form the basal unit of the Mississippi valley alluvial fill. However, there are no known or suspected variations in the lithology or the thickness of these graveliferous deposits that would have resulted in greater densification bencath the sunk lands than beneath adjacent areas.

The lithology of the near-surface sediments in the sunk land areas does not appear to be indicative in regard to sunk land origin. 
These deposits are primarily fine-grained, cohesive materials 10 to $15 \mathrm{ft}$ thick that could have been laid down at any time after cessation of flow in the braided-stream channels. Sufficient organic matter should be preserved locally to permit future age determinations through radiocarbon dating, a procedure that could yield diagnostic results. Dendrochronology is another technique that could possibly prove definitive in sunk land origin assessment provided that stumps or timber dating from the time of the earthquake remain and can be located. This method could indicate the presence or absence of local environmental changes such as subsidence or drowning as would be evidenced by changes in plant growth rates.

\section{SIGNIFICANCE}

The U. S. Coast and Geodetic Survey (1969) has recently prepared and released a new (but interim) seismic risk map of the United States that includes a large portion of the Lower Mississippi Valley in the highest zone of seismic risk (Fig. 1). According to Algermissen (1969), the map is based on three factors: (a) the distribution of Modified Mercalli intensities associated with the known seismic history of the U. S., (b) strain release in the U. S. since 1900, and (c) the association of strain release pattorns with large scale geologic features believed to be related to recent seismic activity. As explained, the zone in the Mississippi Valley is much enlarged over that on the older map to more nearly reflect the probable distribution of intensities in any repetition of the 1811-1812 series.

In anticipation of a seismic risk map in final form, Algermissen (1969) envisions several factor maps, one of which would be geological 
in nature, showing all geological structure thought to be related to seismic activity. Should a map of this type be sufficiently detailed to include particular structural features within a regional trend, it would appear advisable to exclude the St. Francis Sunk Lands for reasons discussed herein. The epicentral line delineated by Fuller (1912) and shown in Figure 1 is no longer tenable when these features are excluded from the list of effects of the 1811-1812 earthquake series. In fact, only sand blows (identification as such probably correct but not ascertained) and an area of fissuring near Marked Tree remain as discernible earthquake effects south and west of Blytheville, Arkansas (Fig. 1). Although there is no reason to question the inferred intensities and magnitudes of the New Madrid earthquake series (Eppley, 1965; Heigold, 1968), and similarly, there is no reason to doubt the validity of Algermissen's (1969) seismic risk zonation as calculated (Fig. I), it appears that much topographic and surface geologic evidence currently are too questionable to be of value in further zonation assessments or refinements. 


\section{REFEREIVCES CITED}

Algermissen, S. T., 1969, Seismic risk studies in the United States:

Preprint of paper, Fourth World Conference on Earthquake Engineering, Santiago, Chile, 10 p.

Broadhead, G. C., 1902, The New Madrid earthquake: Am. Geologist,

v. $30, \mathrm{p} \cdot 76-37$.

Coast and Geodetic Survey, 1969, Map shows areas of U. S. most

vulnerable to earthquakes: U.S. Dept. Commerce, Environmental

Sci. Services Adm., News Release ES 69-1, 4 p.

Eppley, R. A., 1965, Earthquake history of the United States, Part I,

Stronger earthquakes of the United States: U. S. Coast and

Geodetic Survey, $120 \mathrm{p}$.

Fuller, M. I., 1912, The New Madrid earthquake: U. S. Geol. Survey Bull. 494, $119 \mathrm{p}$.

Hansen, W. R., Eckel, E. B., Schaem, W. E., Iyle, R. E., George, W., and Chance, G., 1966, The Aläska earthquake, March 27, 1964:

field investigations and reconstruction effort: U. S. Geol.

Survey Prof. Paper 541, $111 \mathrm{p}$.

Heigold, P. C., 1968, Notes on the earthquake of November 9, 1968, in southern Illinois: Illinois State Geol: Survey Environmental Geology Notes. No. $24,16 \mathrm{p}$.

Krinitzsky, E. I., 1950, Geological investigation of faulting in the

Lower Mississippi Valley: Vicksburg, Miss., U. S. Army Engr.

Waterways Experiment Sta., Tech. Memo. 3-311, 50 p.

Iyeli, Sir Charles, 181+9, A second visit to the United States of North America: London, John Murray, 2 vols., 560 p. 
McGinnis, L. D., 1963, Earthquakes and crustal movement as related to water load in the Mississippi Valley region: Illinois State Geol. Survey Circular 31.4, $20 \mathrm{p}$.

Morse, D. F., 1.969, Introducing northeastern Arkansas prehistory: The Arkansas Archaeologist, v. 10, p. 13-29.

Russell, R: J., 1939, Louisiana stream patterns: Am. Ássoc. Petroleum Geologists Bull., v. 23, no. 8, p. 1199-1227.

Saucier, R. T., 1964, Geological investigation of the St. Francis Basin: Vicksburg, Miss., U. S. Army Engr. Waterways Experiment Sta., Tech. Rept. 3-659, 59 p.

1968, A new chronology for braided stream surface formation in the Lower Mississippi Valley: Southeastern Geology, v. 9, no. 2, p. $65-76$.

Saucier, R. T., and Fleetwood, A. R., 1970, Origin and chronologic significance of Late Quaternary terraces, Ouachita River, Arkansas and Louisiana: Geol. Soc. America Bull., (In Press). Shepard, E. M., 1905, The New Madrid earthquake: Jour. Geology, v. 13, p. $45-62$. 